\title{
Representing Time: Art and Artist
}

\author{
Mg.art. Agita Gritane
}

\begin{abstract}
The proposed paper for the Conference is the insight into Latvian artist Jekabs Bine (1895-1955) life and creative work during 20th century first half. Jekabs Bine was one of the artists of the interwar period who focused on idealized depicting of the Latvian image and search for Latvian identity in the legacy of the past.

All my research aim is regional identity, going through politics, history and art. How changes of political powers during the first half of the 20th century affected an artist who strongly believed in Latvia's identity. I am deeply interested in researching what was an artist's contribution and role in the making of the Latvian identity?

Bine's life and work phenomenon is based on the fact, that the artist dedicated all his life and creative work to find and study the Latvian national identity, in spite of regular political regime shifts in the first half of 20 th century. Being politically and socially active about sharing his national beliefs, Bine's personal character traits and success made it possible not only to escape from the Soviet repression, but also to receive international awards and recognition, as well create significant art works in Latvian history of art in the first half of 20th century.

The aim of the paper is to reveal the circumstances and qualities of this artist's language in cultural, political and historical context.

The research includes the artist's creative experience and the working conditions in the first period of Latvian independence (1918-1940), then followed by the first Soviet occupation (1940-1941), then the German occupation time (1941-1944) and the Latvian inclusion into the Soviet Union (1944). This situation raised the issues of the importance about how artist's creative activities make an impact on the environment and how the environment affects the artist's ability to create and express their creative opinions.
\end{abstract}

Index Terms-Artist, national identity, politics.

\section{INTRODUCTION}

The relationship between art and power at all times and lands have been topical and ambivalent. Art critic and theorist Boris Groys has acknowledged that "Art and politics originally have been connected in one basic aspect: they both are fields where occurs struggle for recognition" [1]. Political regime change conditions most often marks contradictory and unpredictable power and art mutual relationship models. Such situations raise the question of the importance of artist's creative activity impact on the world around you and vice versa, how the environment impacts artist's ability to create and express his creative explorations. The world of art often is forced to abide to power guidelines and objectives. In this context significant and topical seems issue what for an artist

Manuscript received May 5, 2017; revised August 3, 2017.

Agita Gritane is with the Art Academy of Latvia, Kalpaka blv.13, Riga, Latvia (email: agita.gritane@gmail.com). means to live and work in the changing conditions of political power.

Each political power regime in the history of art brings its position reflection, leaving it as a heritage of the past, which often is synthesized with the next period art direction. In studies of art and power relations often disappears the human factor - how at specific circumstances lived and thought the artist - personality that created the art during one or the other power position time and influence. How strong compromise battle was between external manifestations of creativity and ideology?

\section{TIME AND ART}

In most of European countries, Latvia among them, the early part of the 20th century is characterized by rapid changes not only in the sphere of economics and social policy, but also in the fields of culture and the arts, education and science. Within a short span of time, multiple significant shifts in power took place in the territory of Latvia: the foundation of the independent state in 1918, the Soviet occupation in 1940, the occupation by Nazi Germany in 1941, and the second Soviet occupation in 1944. After each shift in power, changes also reflected in all aspects of education.

The aim of this study is to identify how the shifts in political power influenced the process of art and arts education based on the investigation of the specific examples. This study deals with the instances and events experienced by an artist Jekabs Bine (Jēkabs Bīne) (1895-1955) as an artist and educator.

Particularly rapid change of political environment and socio-economic conditions in Latvian territory was observed in the first part of the 20th Century. Views and attitude of ruling political elite influenced the development of cultural policy and priority directions. Such circumstances often changed not only society and the role of culture, but they also affected creative persons' work and freedom of expression. Each power marked different models of society, if during Latvian Independence period dominated hope and faith to its people and the future, then a couple of decades during Soviet power period, biggest part of the same society had to meet fear, fear of losing live, one's people, work, fear to act and express views.

\section{ARTIST JEKABS BINE}

An artist Jekabs Bine is widely known as a painter, an art theoretician, an active supporter and promoter of Latvian national religion call as - Dievturība: the ancient Latvian religion, however, we should not go unmentioned that the pedagogical work played an equally important role in his life. Bine's creative and professional activity has left a rich and 
varied cultural heritage. Having a look at the artist's biography, it can be concluded that, alongside years filled with creative search, Jekabs Bine spent most of his life working as the lecturer in the different educational institutions. This significant part of his life is less well known and studied. The artist gave an exciting and detailed description of his teaching experience in his diaries, notes and letters. As an educator he has been working with prospective students, primary school, as well as professional art schools' learners and the Art Academy's students. Among Bine's students were prospective professionals in the field of art, art lovers and all those interested in art.

Artist Jekabs Bine lived in one of the most troubled and unpredictable periods of Latvian history. During sixty years of life he experienced at least five different power and political turmoil periods.

The artist's life reveals complex contexts with its time historical and political events. Jekabs Bine his talent and imagination was forced variously split between power twists and artistic directions.

Researching Bine's rich artistic heritage, cannot remain unnoticed artist's various and active social and professional activity. He knew how and was able to be seen and heard in all political power "corridors", furthermore actively and convincingly defending his ideas of Latvian culture and beliefs in nation's future.

During Latvian independence period, an important place in Jekabs Bine's public life took Dievturiba. This interest had a significant impact also on the artist's creative work and perception of life in general. Since studies Bine was focused on the research of Latvian ethnography, ornaments and history.

The artist in his creative work was not the initiator of form, but a lot of attention focused on the content of the artwork and plot message [2]. Therefore, despite the time of political confusion, in the context of Latvian art Jekabs Bine can be regarded as the artist who fully devoted his creativity to the efforts to embody in the art works Latvian view of the world, ancient verities of the nation and historical events.

\section{A. The Period of the Independent State of Latvia}

The beginning of Bine's creative work coincided with the Latvian Independence period. In the works of that time is felt the presence of faith and hope, love to family, work and faith in the future of nation that inspired for productive and versatile creative expressions. Artist's life and creative work flourished and reached creative peak in 30 year-end period of the 20th Century, shortly before in Latvia began the period of occupation and power change. Freely and undisturbed Bine almost ten years had been able to develop and promote his views and ideas, in the result artist's creative work got artistically wide and diversified horizons. They were creatively revealed in painting, graphics, research, pedagogical work and social activities. During the first Soviet and German occupation, it seems that Bine still didn't believe in what was happening, he searched for opportunity to continue to believe and work for good to Latvian culture. Painter's works continued to promote the testimonies of nation's history, the role of patterns and images.

During Latvian independence period, together with the growth of national consciousness and national independence, in society was marked realization and revaluation of national and historical value. On the need to build their own - national religion, which would be based on the foundations of past traditions and heritage, was discussed not only in Latvia, it was an actuality also elsewhere in Europe. It manifested more strongly in countries that had gained or regained national independence. Similar examples can be found in Estonia and Lithuania. Dievturiba as Latvian religion was created with the idea that it will give the basis for a new phase in culture and art. Mainly, this assertion was based on the idea that it will be Latvian and national art and culture, in which will not be felt the foreign influence and tradition. The Dievturi were interested in Latvian history, ethnography, mythology, folk art, ancient ornament, traditions [3].

Bine during the time strongly believed in these ideas, and in the result changed the artist's worldview, ethical values. 30 years old, the artist was already active Dievturis, which of course reflected in his works. At this time in his artworks extensively appeared various themes of Latvian mythology. It may be mentioned that during this period developed a different and individual Bine's "idea of Latvian culture" and "nation's ideal". It was based on a belief in the future of nation as historical tradition and wealth heir and the idea mainspring. Bine thoroughly studied the ancient Eastern and African art, searching for references and context with ancient Latvian writings and signs. Valdis Celms in book "Latvian writing and signs" mentions that "Jekabs Bine's merit is other nations' ornament and its meaning research compared with our written testimony [4].

During this period, the artist was able loudly and openly express his ideas and vision, his creativity spirit experienced extensive and diverse manifestations in painting, graphic, theoretical studies and social work.

In 20th -30th years created works repeatedly was depicted Dievturiba theme. Ideologically true and bright Bine as personality characterizes artwork from 1931 "Dievs, Mara, Laima". The painting is important as one of the most expressive and deeply symbolic artist's creative works, and as a visual example of Dievturiba's efforts to revive the spirit of the Latvian deities. The work is saturated with Latvian symbols and signs.

Despite the unsteady and unclear political and social conditions, Bine the whole life not only a lot and productively painted, he also actively participated in various public organizations and more than twenty years worked as a teacher.

Artist Bine actively focused on applied arts. Artist made sketches for furniture, textiles, ceramics and metal products. Bine's applied art creations were characterize by excellent, function convenient design, shape and decoration match. The artist's extensive knowledge and research on folk ornament symbolism, history and folk art gave him opportunities to develop versatile compositions, in which with a help of bright, harmonious colors was highlighted ornament's role and essence.

Some Bine's works gained wide recognition and evaluation, for example, in 1937 after Bine's sketch the coffee set "Nation" which was made in Kuznetsov's porcelain factory, won the gold medal in the worldwide art 
and industry exhibition in Paris. Set was exhibited in the common Baltic States' pavilion Latvian section.

\section{B. The Time of German Occupation}

German occupation Jekabs Bine faced in Riga, actively painting and creatively working in applied arts, continuing teaching in several education institutions and social activities in Dievturi organization.

From 1942 to 1944 Bine gave lectures in Latvian Academy of Art. He worked as an associate professor in mainstream classes and led the plaster head and the portrait class [5].

In 1943 Jekabs Bine took the management of Trade union central union organization "Rest and joy of living" art group. Art scientist Janis Kalnachs in his research "Fine Arts in Latvia under Nazi German Occupation. 1941-1945" mentioned that, the association was developed after in 1935 in Germany established National Socialist organization "Kraft durch Freude" model, putting the idea - "on the beauty of working and proper rest" [6].

In the artist's creative work are not found loud protests against the uncertainty of historical situation, unfairness or open pain for what is happening. Bine internally believed in and was confident about the future of the Latvian nation's independent future and sometimes loudly, sometimes quietly expressed it in his works and views. Obeying to the political power's conditions in the artist works expressed views are nuanced, using detailed signs and colors to convey the message to people who hold the same views and his talent lovers. As an amazing exception both the artist's creative work and in Latvian art as a whole should be mentioned in 1942 in Kuldiga created Bine's work "Snow-covered path", for which the art scientist Janis Kalnachs mentions, that "Extremely rare Nazi German occupation time art motif war or terror victims' body as century marked staffage appears in Bine's "Landscape (Snow-covered path) [6]. The artist's strong believes and inner courage appear in other German occupation time work, but in the last war in the spring in Kuldiga created "Secondary school girl's Livija Rezevska's portrait" (1945), painting candles, he emphatically used the destroyed Latvia's national flag's color [7].

\section{The Period of Soviet Power}

The first years after the Soviet power strengthening in Latvian territory Bine spent in Kuldiga. The artist continued to work as a teacher in Kuldiga secondary school, but in 1946 was one of the first who started Kuldiga Craftsman secondary school establishment. In his beliefs and actions Bine was deeply convinced of the chosen path, therefore often he had to experience disappointment. He believed in fair attitude to work, people and what is being said, but did not understand what is happening in the corridors of power and the work of political supervision system. In the memory of Jekabs Bine's contemporaries he remains as fair and firm spokesman of his opinions and ideas, sympathetic teacher and confident artist.

Living and working in Kuldiga, Bine tried quietly and unnoticeably performs his direct responsibilities at school and quietly continued to study and to speak about Latvian history, ornament, antiquity and its importance. However, in 1950, when to the public came artist's work during the independent Latvian state, he had to leave the Kuldiga Craftsman school and Bine moved back to Riga.

During the Soviet period Bine survived Soviet artist's living reality. During work the artist led complex "Art" stained glass workshop and made a Soviet propaganda orders in which portrayed Communism promised utopian life future and portrayed Stalin, Lenin and other heroes of that time. Whereas, at free time he tried to paint and explore close and essential subjects for himself, for example in 1952 Bine turned back to Dievturiba theme when he was 30 years old and painted a new version of the painting "Dievs, Mara, Laima".

Now it is difficult to judge how hard it was to live as "walking on a knife's edge", what inner emotions and experiences have been suppressed and what compromises with his conscience had an artist. However, Jekabs Bine tried to hide his thoughts, between the lines and words they were readable and understandable.

In abroad-released periodical "Latvju ziņas", describing scandals, in which was involved artist, is said "Latvian ornament researcher and recognizer Jekabs Bine's sin list is huge, and from Siberia he can be saved only by his craftsmanship - Jekabs Bine is one of the people, who is making stained-glass for Moscow metro stations, which express the greatness of Stalin's era.

Because of the artist's social activities suffered also Jekabs Bine's wives. The attitude of Soviet power against Bine's former art pieces was negative. His name can be found among the artists whose works placed in special storage [8]. Art historians, researchers and museum scientific staff members could be acquainted with works included in funds only with written permission of Art affairs member of the board and only in the premises of special storage in the presence of responsible person and registration in a special register. In special storage came not only artist's art works, but also its photo negatives and copies. It should be mentioned that the Soviet regime was generally characterized by believing that art almost started only after 1940 and 1945 .

Bine tried in his works to express nation's national identity and power through realistic forms. His artistic content was Latvian identity, which he tried to find in nation's mythology, history and ancient ornaments synthesis. This content searches confused and broke Bine at the Soviet time, when he felt as "thrown out of the boat". During the Soviet period created paintings are more illustrative, less emotional and narrative. Unable to realize his content ideas or find new ones that would be suitable for the Soviet beliefs and principles, the artist replaced the quality against quantity. Bine painted a lot, experimented and searched, but the results that would satisfy him, was not reached. There was nothing to paint about. He created myriad of still life and landscape paintings, as well as genre art and custom portraits. Occasionally, the artist repeatedly painted work versions, which were created in recent years.

In the summer of 1955 Bine was awarded for achievements in art of stained glass with Latvian SSR merited art worker honor title. The artist wrote about this event "on 21 st July I read in a newspaper - that I have been awarded as "merited art worker". 


\section{EDUCATOR JEKABS BINE}

Having a look at the artist's biography, it can be concluded that, alongside years filled with creative search, Jekabs Bine spent most of his life working as the lecturer in the different educational institutions. This significant part of his life is less well known and studied. The artist gave an exciting and detailed description of his teaching experience in his diaries, notes and letters. As an educator he has been working with prospective students, primary school, as well as professional art schools' learners and the Art Academy's students. Among Bine's students were prospective professionals in the field of art, art lovers and all those interested in art.

On the basis of the educational qualification and practical experience on 6 April 1938 Jekabs Bine received the certificate No. 4468 issued by the School Department of the Ministry of Education, which certified that he is a certified secondary school teacher to be entitled to teach drawing and art history. The archive keeps the educational documents that in 1913 Jekabs Bine graduated with distinction Riga City Commercial School, but on 30 September 1937 he took out the diploma No. 154 issued by the Art Academy of Latvia, certifying that in 1926 he graduated the Workshop of Figurative painting and obtained a degree of the artist painter with all statutory rights. It is worth mentioning that Jekabs Bine studied at the Riga City Art School from 1913 to 1915, his lecturers were Valkers and Vilhelms Purvitis. At the beginning of World War I, Bine went to Kharkov and continued his studies at Kharkov Art School. When the revolution and War interrupted the functioning of Kharkov Art School as well, Jekabs Bine returned to Riga for a short time, but in 1919 he moved back to Kharkov. Here for the first time he began to teach painting and drawing skills to others.

It can be said that in Kharkov he had his first pedagogical experience. In 1919, when living in Kharkov, he performed various jobs to earn his living. At that time he had no time for painting therefore in 1920 on receipt of the tack to lead the painting studio of the Latvian Workers' Association "Work", the artist was very glad because he was always much more willing to practice his hand in painting. In this studio was attended by about 10 listeners. The artist gave lessons for those interested in drawing and painting basics.

His first skills in pedagogical work Bine acquired working as the teacher at the art studio and a private teacher. Jekabs Bine's length of educator's continuous service was more than 20 years, and almost all of these years he lectured and conducted training sessions in a number of educational institutions.

The artist accepted his invitation and started to work as a teacher at Kuldiga Secondary School of Craftsmanship.

At the time when Bine entered the service, he had to be assumed that his belief in traditional Latvian religion of Dievturiba and love for all traditional Latvian values must be the secret. However, within the teaching process Bine found the ways to talk round and explore the Latvian ornament, history and national belonging. How hard it was to combine formal educational instructions and recommendations with his beliefs and certain views expressed in his art works is anybody's guess.

The documentary archive keeps the order No. 251, issued by the National historical museum DOMS on 22 May 1947, by which Jekabs Bine wrote, that it is obliged to promote the collection, selection and delivery of amateur works of applied arts located in your district to the Republican exposition in Riga, at the Central State Historical Museum Pioneer Palace, in cooperation with the Head of the Cultural-Education Department of your district [9]. On progress report immediately 4 Palasta Street, Riga. Probably, under the influence of this received task, while working at Secondary School of Craftsmanship, Bine organized the Folk Art Research Society. Together with the learners of this Society we collected more that 1500 ancient collection items. He was a regular lecturer, a number of lectures were preserved, for instance, the Ancient Kyiv, Culture of Cinerary Urns in the Dnieper Region, the Stone Age Finds in Latvia, The History of Kuldiga etc.

On 7 November 1947 when working at at Kuldiga Secondary School of Craftsmanship Jekabs Bine was awarded the award of the Art Affairs' Administration of the LSSR Council of Ministers for a successful work in the development of Latvia SSR's art.

Bine's notes characterize post-war difficulties and day-to-day school activities. The educator mentioned that lessons were repeatedly cancelled because electricity was cut off or on another occasion the lessons had not taken place as the first year girls sawed wood. Various daily problems alternated with the political propaganda of that time, for example, on 25 February the lesson did not happen because during the first lesson the reading of the Party appeal took place, or on 10 March from the last lessons learners were sent to help in the election work. On some other day teaching process was disturbed by the order to go to the forest for trees, due to cleaning works at school or the sugar-beet joint work.

On 16 July 1951 Jekabs Bine wrote in his diary: “.... M. Furmanis (Director of that time of Kuldiga Secondary School of Craftsmanship) dismissed me - suggested resign. It was the five-year anniversary present because this autumn 5 years ago I started to work at Kuldiga Secondary School of Craftsmanship..... and at the same time dismissed Milda (Anna Milda Ernests's d. Bine born Purina, Jekabs Bine's second wife, worked at Kuldiga Secondary School of Craftsmansh as a Housekeeping teacher as well [9]. That is an order by Comrade Andersons (Head of Propaganda Department)." It must be noted that Director could dismiss Bine in more formal way. A request to resign at that time provided greater opportunities to find the next job in relation to his profession. The real reason for his dismissal was a report by Kuldiga Party Committee in which Jekabs Bine's activities during the period of Free State of Latvia, during the inter-war period and during the occupation by Nazi Germany were stated.

Trying to find out the reasons of his dismissal Bine later, in his diary, after his meeting with the leaders in Riga, wrote "In front of me there were shown "Eras (Laikmeti)", where I had been written a obituary notice for Dzervitis, wrote about jewelry and the summer solstice - such ideology is incongruous with our age and I am no-good as a teacher [9].

Despite this invalid ideology, in 1950 Jekabs Bine had received a number of awards the Art Affairs' Administration of the LSSR Council of Ministers for a successful creative 
activity and work in the development of Latvia SSR's art. With this vague and inconsistent evaluation of his work the artist had to deal with and continue to realize his creative ideas.

\section{CONCLUSION}

Art and politics are often much more closely connected than it seems at first glance. Furthermore, the role and importance of interaction is different in different periods, often the greatest role is playing political context and only then follows artistic criteria.

Following the artist's creative work, it can be concluded that the 20th -30 th year period was his creative growth. During this time Bine was able freely express his ideological convictions both in theoretical studies as well as works of art. In later years the political and cultural changes put for the art other requirements. During this time the government's attitude towards all national manifestations was not unambiguous. It was against the Dievturi efforts to restore Latvian world and life views. In order to continue to work Bine, at least outwardly, tried to adapt to the new conditions. However, silently, in his thoughts and deeds, he expressed his ideological beliefs. During Soviet time, the artist's creative spirit became quieter and his works became less emotional, without deep symbolic search and the presence of creative inspiration.

In conclusion, the artist's creative work and accomplishments has been positively assessed from various points of view of political power conditions. Bine received scholarships and awards for his works during the period of Latvian independence and the Soviet power period.

It remains to guess whether success and friends' support in a difficult moment saved the artist from exile and prison chambers, but Bine's life shows that inner struggle between personal beliefs and adaptation to external conditions breaks human life inappropriately early, so the artist's life came abruptly to an end suddenly at the age of 60. The artist's funeral becomes silent, in words unsaid protest against power, but the main thing - it is acknowledgement to the Artist,
Latvian, Labietis [10].

\section{REFERENCES}

[1] B. Groys, The Power of Art, Riga: The Latvian Centre for Contemporary Art, 2015, p. 22.

[2] Dz. Bluma, S. Cielava, R. Caupova, V. Kucinska, Z. Kuple, R. Lace, V. Lapacinska, and I. Novadniece, Latviešu Tēlotāja Māksla, 1860-1940, Rīga: Zinātne, 1986, p. 499.

[3] E. Brastiňš, Tautai, Dievam, Tèvzemei, Rīga: Zvaigzne, 1993, p. 192.

[4] V. Celms, Latvju Raksts un zīMes, Rīga: Folkloras informāCijas Centrs, 2007, p. 272

[5] M. Brancis, Jēkabs Bīne, Rīga: Preses Nams, 1995, p. 47.

[6] J. Kalnachs, Fine Arts in Latvia under Nazi German Occupation. 1941-1945, Riga: Neputns, 2005, p. 121.

[7] I. Dislere, I. Lagzdins, E. Rozenfelds, A. Sablovskis, and M. Plesuma, Spēes ar mēRnieku Laikiem, Talsi: Tumes Pagasta Padome, 2009, p. 350.

[8] Z. Konstants, "Riga Museums in Occupation Years. 1940-1990," in Doma 5 Art theory, History and Critics. Association of Latvian Museums of Art, Riga: DOMA, 2000, p.159.

[9] The National Archives of Latvia, Archive Collection, no. 1757.

[10] M. Brancis, Jānis Roberts Tillbergs, Rīga: Zinātne, 1996, p. 306.

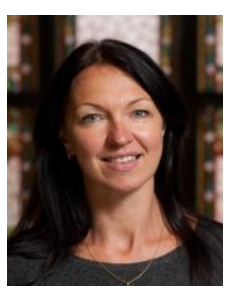

Agita Gritane is a doctoral student and her doctoral thesis is a monographic research about one of the most controversial Latvian artist Jekabs Bine (1895-1955) Agita Gritane is deeply interested in researching what was an artist's contribution and role in the making of the Latvian identity? How changes of political powers during the first half of the 20th century affected an artist who strongly believed in Latvia's identity.

Currently Agita Gritane works at the Art Academy of Latvia as educational assistant and also as a lecturer at University of Liepaja. She has a master degree in law of social sciences and master of arts degree in the humanities. After successful work in the legal research area, she changed her direction and started to study at Art Academy of Latvia. During her master studies she spent one semester at University of Barcelona.

Parallel to her studies at the Academy she worked at local art galleries to gain practical experience. Agita Gritane also has theoretical publications in journals and art reviews and the other authors may include biographies at the end of regular papers.

The bachelor thesis subject was "Research and survey on Latvian national religion impact, expression trends and diversity in Latvian painting art of 20th century during the interwar period 20-30." In master thesis author continued research about artist's Jekabs Bine life and creative work. 